\title{
Accumulation of the betaine and ectoine in osmotic stress adaptation of biocontrol agents against Fusarium verticillioides in maize
}

\author{
Melina Sartori ${ }^{1}$, Andrea Nesci $^{1}$, Naresh Magan $^{2}$, Miriam Etcheverry $^{1^{*}}$ \\ ${ }^{1}$ Laboratorio de Ecología Microbiana, Departamento de Microbiología e Inmunología, Facultad de Ciencias Exactas, Físico Químicas \\ y Naturales, Universidad Nacional de Río Cuarto, Río Cuarto, Argentina; \\ *Corresponding Author: metcheverry@exa.unrc.edu.ar \\ ${ }^{2}$ Applied Micology Group, Cranfield Health, Vincent Building, Cranfield University, Cranfield, UK
}

Received 9 October 2011; revised 26 November 2011; accepted 23 December 2011

\begin{abstract}
The aims of this study was to examine the effect of the osmotic $(\mathrm{NaCl})$ water stress on, growth and accumulation of endogenous compatible solutes of Bacillus amyloliquefaciens and Microbacterium oleovorans, biocontrol agents against Fusarium verticillioides. Triptic soya broth media were modified ionically to $0.99 ; 0.98 ; 0.97$ and $0.96 \mathrm{a}_{\mathrm{w}}$ with $\mathrm{NaCl}$. The endogenous contents of the intracellular compatible solutes glycinebetaine and ectoine were quantified. Cells grown under ionic solute stress showed accumulation of significant amounts of both amino acids in all treatments. The growth rate of $F$. verticillioides was decreased significantly by interaction with $B$. amyloliquefaciens and $M$. oleovorans physiologically adapted at $0.96 \mathrm{a}_{\mathrm{w}}$. This study have demonstrated the ability to synthesize betaine and ectoine under high-osmolality conditions of $B$. amyloliquefaciens and M. oleovorans cells. Such ecophysiological manipulation, especially to water stress, may increase the potential for biological control of $F$. verticillioides at field under wider $a_{w}$ conditions.
\end{abstract}

Keywords: Biological Control; Osmotic Adaptation; Solute Compatible; Fusarium verticillioides; Maize

\section{INTRODUCTION}

Fusarium verticillioides is considered to be a primary phytopathogen of maize, occuring world wide in tropical and subtropical zones. The pathogen life cycle is significantly influenced by environmental factors specially water availability and temperature [1]. F. verticillioides produce a large number of microconidia and macroconidia on crop residues, and these asexual spores comprise the most important inoculum for Fusarium ear rot and symptomless kernel infection. F. verticillioides can be transmitted from seeds to seedling and can also systemically colonize the entire maize plant without any visible symptoms. This causes transmission from seed to plant to kernels. Another route is for airborne spores to infect through the silks [2]. Kernels can also be infected by $F$. verticillioides strains that originate from the rhizosphere. The relative importance of different pathways may vary in different geographic areas [3]. F. verticillioides can produce fusaric acid, fusarins and mainly, fumonisins, clearly the most important toxin produced by the fungus $[4,5]$. The consumption of fumonisins contaminated maize based foods has been correlated with high rate of human esophageal cancer in Transkei and China [6,7]. Fumonisin $B_{1}$ is considered as carcinogen type $2 B$ [8]. There are recommended maximum fumonisin levels adequate to protect human and animal health $[9,10]$. Thus strategic for minimizing or reducing the infection by these Fusaria and fumonisin contamination are being sought.

One approach is the use of biocontrol micro-organisms which can effectively outcompete the mycotoxigenic strains. Previous studies have shown that the addition of Bacillus amyloliquefaciens and Microbacterium oleovorans to seeds significantly reduced $F$. verticillioides populations in the root inner tissues of resultant seedlings and also subsequently reduced fumonisin $\mathrm{B}_{1}$ and $\mathrm{B}_{2}$ content of maize grain at harvest [11-13]. This type of biocontrol action may be by competitive exclusion of the pathogen. In this way both biocontrol agents are able to colonise the rhizosphere and minimize the opportunity for colonization during the criticial early days of plant development. However, such soil microorganisms are exposed to fluctuating and often very dry conditions (reduced water potentials) because of soil matric potential stress and in some cases solute water potential stress in saline soils [14].

Teixidó et al. $[15,16]$ suggested that it is possible to 
significantly improve environmental stress tolerance of biocontrol agents by physiologically growing them under conditions which facilitate synthesis of useful compatible solutes. Thus there is interest in whether the two bacteria in this study can be grown so that the environmental tolerance can be improved for better efficacy in the rhizosphere during the initial germination and establishment of maize seed. This could also have implications for the effective formulation of such bacteria in the preparation of dry formulations with conserved viability and shelflife [17].

Previously, we have demonstrated that B. amyloliquefaciens and $M$. oleovorans were more tolerant to ionic and non-ionic potential stress that matric potential stress and showed tolerance to heat-shock of the $45^{\circ} \mathrm{C}$ in a physiological adaptation assays [18]. Previous studies have also shown that growth on MSB medium (molasses soy powder broth) and subsequent freeze drying of $B$. amyloliquefaciens and $M$. oleovorans cells had good viability, regardless of the water stress treatment used [19]. This suggests that growth under ecophysiological stress conditions can result in the synthesis of compatible solutes to help overcome water stress and to enable the cell functioning to continue under environmental stress [20]. Compatible solutes can make important contributions to the restoration of turgor under conditions of low water activity by counteracting the efflux of water from the cell. Important representatives of this class of molecules are the amino acid proline, the trimethylammonium compound glycine-betaine and tetrahydropyrimidine ectoine [21]. The accumulation of all or some of these compounds enables cell proliferation under unfavourable environmental stress conditions [22]. An additional role for compatible solutes is that they can also mitigate deleterious effects of heat stress, freezing, drying, hight salinity, oxygen radicals, radiation, urea and other denaturing agents on the integrity of proteins, nucleic acid, biomembranes and even whole cells [23,24].

The objective of this work were to determine the effects of water potential stress on bacterial growth in liquid medium, to quantify the accumulation of glycinebetaine and ectoine in cells of the potential biocontrol agents B. amylolyquefaciens and M. oleovorans, and to determine the effect of physiological adaptation of both bacteria in antifungal activity.

\section{MATERIALS AND METHODS}

\subsection{Bacterial Strain}

The strains used in this study were Bacillus amyloliquefaciens (GenBank accession EU164542 and BNM 0531 ) and Microbacterium oleovorans (GenBank accession EU164543 and BNM 0532) [12]. These strains were isolated from a commercial maize field and identified on the basis of 16S DNA gene sequence similarity and additionally identified based on their physiological profiling according to Bergey's Manual of Systematic Bacteriology [25]. These strains are deposited in the National Bank of Microorganisms, dependent of Biosciences Research Institute in Agricultural and Environmental (INBA) and National Council of Scientific and Technical Research (CONICET), National University of Buenos Aires, Buenos Aires, Argentina.

\subsection{Growth under Osmotic Stress in Liquid Medium}

B. amyloliquefaciens and $M$. oleovorans were initially grown in TSB medium (tryptic soy broth), and osmoticcally modified to $0.99,0.98,0.97$ and $0.96 \mathrm{a}_{\mathrm{w}}$ by addition of the ionic solute $(\mathrm{NaCl})$ [26], the $\mathrm{a}_{\mathrm{w}}$ of control treatments was 0.99 . For each treatment, $150 \mathrm{~mL}$ medium in conical flasks $(250 \mathrm{~mL})$ were inoculated with 1 $\mathrm{mL}$ of $10^{4} \mathrm{CFU} \cdot \mathrm{mL}^{-1}$ and cultured on a rotatory shaker $(140 \mathrm{rpm})$ at $30^{\circ} \mathrm{C}$ for $24 \mathrm{~h}$. After incubation samples were spread-plate on TSA medium and incubated at $30^{\circ} \mathrm{C}$ and the number of viable cells was determined after $24 \mathrm{~h}$. All cell cultures of B. amyloliquefaciens and $M$. oleovorans were centrifuged for $10 \mathrm{~min}$ at $7000 \mathrm{~g}$ and $10^{\circ} \mathrm{C}$. Cells were harvested in sterile tubes. Three replicates per treatment were used and the experiments repeated twice.

\subsection{Determination of Endogenous Glycine-Betaine and Ectoine Accumulation}

The bacterial pellet of B. amyloliquefaciens and $M$. oleovorans cell treatments were resuspended in $2 \mathrm{~mL}$ of skim milk and frozen at $-20^{\circ} \mathrm{C}$ for $24 \mathrm{~h}$. Then samples were connected to the freeze-drier operating at chamber pressure $<0.05$ mbar and $-45^{\circ} \mathrm{C}$ for $24 \mathrm{~h}$. Extraction was done using the method described by Kunte et al. [27]. Firstly, to obtain endogenous compatible solutes, $20 \mathrm{mg}$ of freeze-dried cells were added to $570 \mu \mathrm{l}$ of extraction mixture (methanol/chloroform/water 10:5:4 by vol.) by vigorous shaking for $5 \mathrm{~min}$. Immediately, equal volumes $(170 \mu \mathrm{l})$ of chloroform and water were added and the mixture shaken for another $10 \mathrm{~min}$. Phase separation was enhanced by centrifugation at $9720 \mathrm{xg}$ and $10 \mathrm{~min}$. The hydrophilic top layer containing the compatible solutes was recovered and diluted to suitable concentrations (low $\mu \mathrm{M}$ range) prior to analyses by high performance liquid chromathography (HPLC).

An aliquot of $0.75 \mathrm{ml}$ of acetronitrile (ACN) was added to each sample to obtain the same ratio of acetonitrile/water (80:20) as mobile phase for component separation. The samples were centrifuged at $9720 \mathrm{xg}$ during $10 \mathrm{~min}$ to discard impurities and before HPLC analysis and the liquid filtered through a $0 \cdot 22 \mu \mathrm{m}$ (What- 
man) sterile filter unit. The samples (50 ul) were injected and analysed using a $\mathrm{RP} 8-\mathrm{NH}_{2}$ column $(125 \times 4 \mathrm{~mm}$ filled with $3 \mu \mathrm{m}$ Gromsil amino 100 RP-8; Grom Analytic, Rottenburg-Hailfingen, Germany) using an autosampler. The flow rate of the mobile phase was 1.5 $\mathrm{ml} \cdot \mathrm{min}^{-1}$ at room temperature. Glycine-betaine and ectoine were detected with an Agilent Refractive index (RI) Detector (Agilent G1362A module) and an autosampler connected to the Agilent Millenium software package for data analyses. The peak areas were integrated and compared with calibration curves constructed with standards (50 - $800 \mu \mathrm{mol} \cdot \mathrm{g}^{-1}$ ) of each component analysed. Results were expressed as $\mu \mathrm{mol}$ compatible solute $\mathrm{g}^{-1}$ (dry weight bacterial cells). All results are the mean of three replicate freeze-dried bacterium samples per treatment condition.

\subsection{Influence of Physiological Adaptation of Antagonistic Agents on Growth Rate of F. verticillioides}

The inhibitory activity on lag phase and growth rate of $B$. amyloliquefaciens and $M$. oleovorans against $F$. verticillioides were tested. Culture medium for bacteria, at different water activity levels and control unmodified was prepared following the procedure used for growth under osmotic stress assessment. The basic medium used was maize meal extract agar (MMEA) containing 3\% maize meal and $1.5 \%$ agar. The water activity of the basic medium was adjusted to $0.99,0.98,0.97$ and 0.96 by the addition of $\mathrm{NaCl}$, according to Dallyn and Fox [26]. Each bacterial suspension with $10^{8}$ cells $\cdot \mathrm{ml}^{-1}$ was pourplated in $20 \mathrm{~mL}$ of MMEA and after solidification, MMEA were inoculated with $10 \mu \mathrm{L}$ of $10^{4}$ spores $\cdot \mathrm{mL}^{-1}$, obtained form 7 days sporulated media Capellini-Peterson [28], in the centre of each plate. Treatments were incubated at $25^{\circ} \mathrm{C}$ for 12 days in polyethylene bags. This assessment was carried out with three separate replicates per treatment. The colony radius was measured daily. For each colony, two radii, measured at right angles to one another, were averaged to find the mean radius for that colony. The radial growth rate $\left(\mathrm{mm} \cdot \mathrm{d}^{-1}\right)$ was subsequently calculated by linear regression of the linear phase for growth and the time at which the line intercepted the $\mathrm{X}$-axis was used to calculate the lag phase in relation to bacteria and water activity.

\subsection{Statistical Analysis}

Analysis of variance (ANOVA) was made for viable counts in unstressed and water-stressed media, endogenous glycine-betaine and ectoine accumulation and lag phase and growth rate using a SAS program (SAS System for Windows 6.11. SAS Institute, Cary, NC, USA). To establish the significant differences, Duncan's multi- ple range test $(\mathrm{P}<0.05)$ was performed.

\section{RESULTS}

\subsection{Osmotic Potential Effects on Bacterial Growth in Liquid Medium}

The viability of $B$. amyloliquefaciens and $M$. oleovorans, in physiological adaptation assays to water stress in broth media under ionic stress, after $24 \mathrm{~h}$ of incubation showed statistically significant differences between diferent water activities (see Figure 1). No significative differences in the CFU count was observed between 0.99, 0.98 and $0.97 \mathrm{a}_{\mathrm{w}}$, the highest count of $B$. amyloliquefaciens was $\log 10.37 \mathrm{CFUs} \cdot \mathrm{ml}^{-1}$ at $0.99 \mathrm{a}_{\mathrm{w}}$, and the lowest at $\log 9.23 \mathrm{CFUs} \cdot \mathrm{ml}^{-1}$ at $0.96 \mathrm{a}_{\mathrm{w}}$. For M. oleovorans the highest cell count was observed at $0.99 \mathrm{a}_{\mathrm{w}}$, with $\log 7.78 \mathrm{CFUs} \cdot \mathrm{ml}^{-1}$ and the lowest was $\log 4.93$ CFUs $\cdot \mathrm{ml}^{-1}$ at $0.96 \mathrm{a}_{\mathrm{w}}$. The number of cells obtained for both bacteria was significantly $(\mathrm{P}=0.05)$ decreased at $0.96 \mathrm{a}_{\mathrm{w}}$.

\subsection{Accumulation of Betaine and Ectoine in Bacterial Cells}

Endogenou s accumulation of ectoine and glycine-betaine in B. amyloliquefaciens and $M$. oleovorans cells grown under ionic stress are shown in Figures 2 and 3. All cells grown under ionic solute stress $(0.99,0.98,0.97$ and $0.96 \mathrm{a}_{\mathrm{w}}$ ) showed an accumulation of both compatible solutes. The highest glycine-betaine accumulation in cells of B. amyloliquefaciens was $511.37 \mu \mathrm{mol} \cdot \mathrm{g}^{-1}$ at $0.98 \mathrm{a}_{\mathrm{w}}$. At $0.97 \mathrm{a}_{\mathrm{w}}$ accumulation of glycine-betaine was significantly lower with about $232 \mu \mathrm{mol} \cdot \mathrm{g}^{-1}$ being present (see Figure 2). For the second bacterium examined,

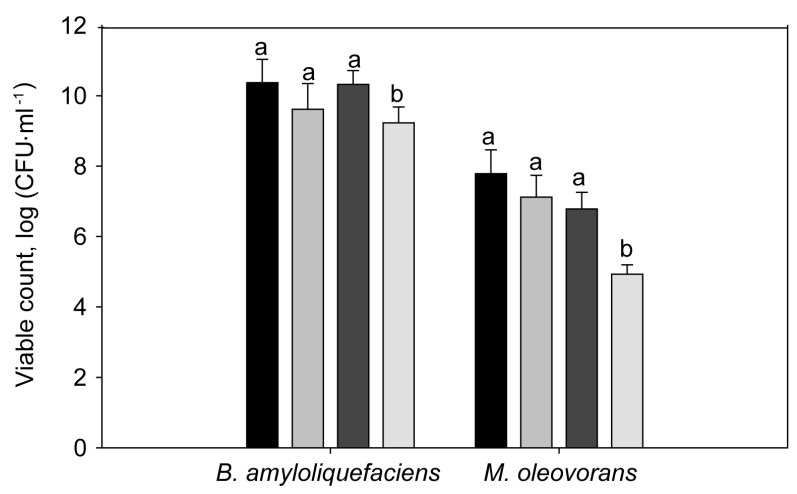

Figure 1. Viability of B. amyloliquefaciens and M. oleovorans cell growth in stressed liquid media $\left(0.99 \mathrm{a}_{\mathrm{w}} \mathbf{\square}, 0.98 \mathrm{a}_{\mathrm{w}} \square\right.$, $0.97 \mathrm{a}_{\mathrm{w}} \square$ and $0.96 \mathrm{a}_{\mathrm{w}} \square$ ), after incubation at $30^{\circ} \mathrm{C}$ for $24 \mathrm{~h}$. Statistical analysis was performed on different water activities. Bars represent means and standard deviation of treatment replications. Data with the same letter for different water activities are not significantly different according to Duncan's multiple range test $(\mathrm{P}<0.05)$. 


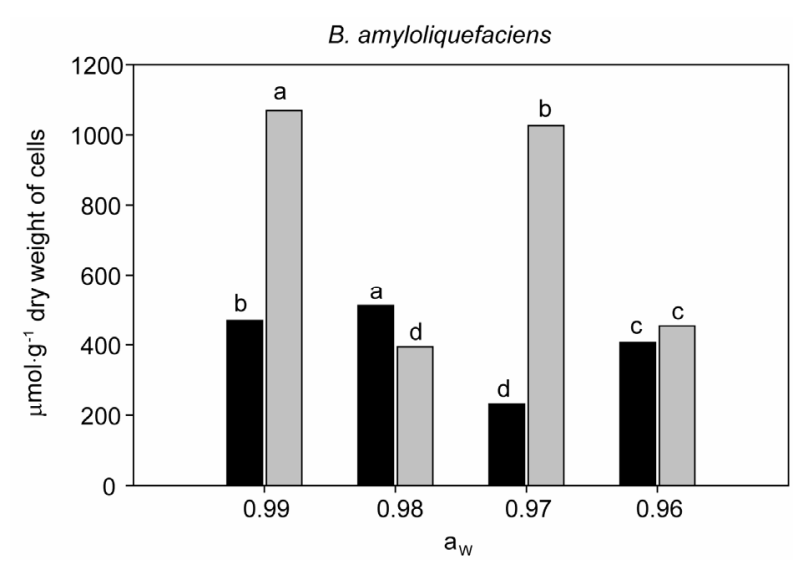

Figure 2. Accumulation of intracelular betaine ( $\square$ ) and ectoine $(\square)$ in B. amyloliquefaciens growth for $24 \mathrm{~h}$ at $30^{\circ} \mathrm{C}$ in TSB modified with $\mathrm{NaCl}$ at $0.99 ; 0.98 ; 0.97$ and $0.96 \mathrm{a}_{\mathrm{w}}$. Results are mean values of three replicates per treatment. Data with the same letter for different water activities are not significantly different for each compatible solute, according to Duncan's multiple range test $(\mathrm{P}<0.05)$.

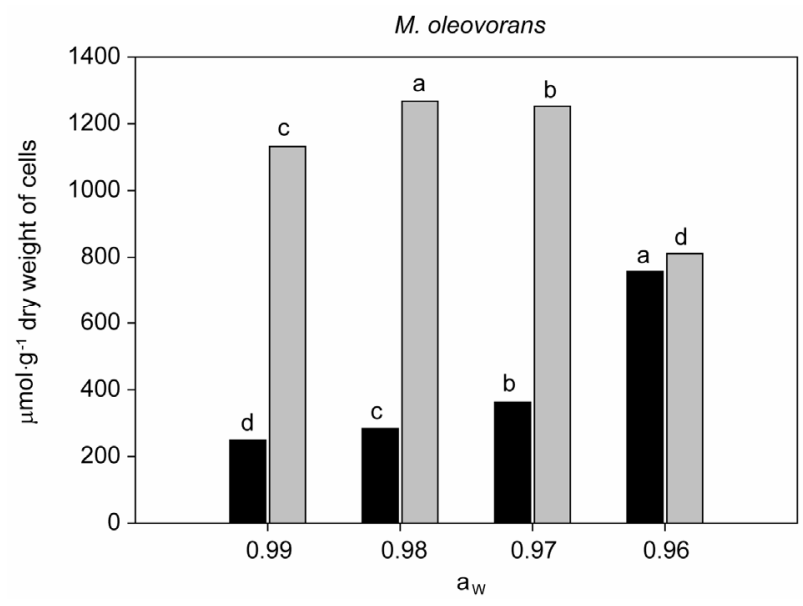

Figure 3. Accumulation of intracelular betaine ( $\square$ ) and ectoine $(\square)$ in M. oleovorans growth for $24 \mathrm{~h}$ at $30^{\circ} \mathrm{C}$ in TSB modified with $\mathrm{NaCl}$ at $0.99 ; 0.98 ; 0.97$ and $0.96 \mathrm{a}_{\mathrm{w}}$. Results are mean values of three replicates per treatment. Data with the same letter for different water activities are not significantly different for each compatible solute, according to Duncan's multiple range test $(\mathrm{P}<0.05)$.

M. oleovorans, the glycine-betaine accumulation was higher at $0.96 \mathrm{a}_{\mathrm{w}}$ with $758 \mu \mathrm{mol} \cdot \mathrm{g}^{-1}$ and this was again significantly higher than other treatments at $0.99,0.98$ and $0.97 \mathrm{a}_{\mathrm{w}}$. The lower concentrations were found in the $0.99 \mathrm{a}_{\mathrm{w}}$ treatment with $249 \mu \mathrm{mol} \cdot \mathrm{g}^{-1}$ (see Figure 3).

The ectoine accumulation in cells of $B$. amyloliquefaciens was $1070 \mu \mathrm{mol} \cdot \mathrm{g}^{-1}$ at $0.99 \mathrm{a}_{\mathrm{w}}$ and this was statistically different from the other $\mathrm{a}_{\mathrm{w}}$ levels tested $(0.98,0.97$ and 0.96), less ectoine was accumulated in these cells at $0.98 \mathrm{a}_{\mathrm{w}}$. In contrast $M$. oleovorans cells accumulated very high concentrations of ectoine at this $\mathrm{a}_{\mathrm{w}}$ level (0.98) with
$1268 \mu \mathrm{mol} \cdot \mathrm{g}^{-1}$. This was shown to be statistically significant from the other $a_{w}$ levels tested. The lowest ectoine concentration was at $811 \mu \mathrm{mol} \cdot \mathrm{g}^{-1}$ at $0.96 \mathrm{a}_{\mathrm{w}}$ (see Figure 3).

\subsection{Effects of Antagonistic Agents on Growth of $F$. verticillioides}

The lag phase and growth rate of F. verticillioides of paired cultures at different water activities are shown in Table 1. Antagonistic agents produced a significant increase in the lag phase and decrease in the growth rate of F. verticillioides $(\mathrm{P}<0.001)$. The lag phase of control cultures of $F$. verticillioides increased when water activities of the medium decreased in all treatments. Both antagonistic agents caused increase of lag phase of $F$. verticillioides. The lag phase of $F$. verticillioides was increased significantly by interaction with $B$. amyloliquefaciens physiologically adapted at 0.97 and $0.96 \mathrm{a}_{\mathrm{w}}$, the values ranged between $7.26 \mathrm{~h}$ and $8.56 \mathrm{~h}$ respectively. $M$. oleovorans also showed significative differences in lag phase between control and interaction with bacteria physiologically adapted at 0.98 and $0.96 \mathrm{a}_{\mathrm{w}}$ with values ranged between $7.42 \mathrm{~h}$ and $8.47 \mathrm{~h}$ respectively. In addition, the effect of $B$. amyloliquefaciens physiologically adapted on lag phase was higher at the lower water activities assayed.

Changes in $\mathrm{a}_{\mathrm{w}}$ alone of control treatments reduced growth by more than $35 \%$ between 0.99 and $0.96 \mathrm{a}_{\mathrm{w}}$. Growth of bacteria F. verticillioides interactions was always more inhibited at lower $\mathrm{a}_{\mathrm{w}}$ values. B. amyloliquefaciens and $M$. oleovorans without physiological adaptation produced the greatest reduction of growth rate of $F$. verticillioides at 0.97 and $0.98 \mathrm{a}_{\mathrm{w}}$ respectively, with values of 0.19 and $0.37 \mathrm{~mm} \cdot \mathrm{h}^{-1}$ respectivelly. B. amyloliquefaciens physiologically adapted gave greater than $55 \%$ control at $0.96 \mathrm{a}_{\mathrm{w}}$, while $M$. oleovorans gave more than $50 \%$ control of the pathogen at 0.98 and $0.96 \mathrm{a}_{\mathrm{w}}$.

\section{DISCUSSION}

Several previous studies have demonstrated the effecttiveness of these biocontrol agents on toxigenic F. verticillioides in vitro, in situ [29-32] and at field level [11-13, 33]. For a biofungicide agent can be successfully marketed, the stages of formulate preparation are important to ensure the survival of biocontrol agents against environmental fluctuations and survival in the stage of storage [34]. Dehydration of a microbial culture and maintenance in low water availability is one of the best ways to formulate microbial agents and enhance survival of biofungicide to facilitate its handling at points of sale and distribution of pesticides. Not all the biological control agents are likely to be subjected to dehydration and can lose viability conditions. In this sense, to improve seed 
Table 1. Effect of bacteria - F. verticillioides interactions on the lag phase and growth rate at different water activities.

\begin{tabular}{|c|c|c|c|}
\hline Water activity & Treatments & Lag phase (h) & Growth rate $\left(\mathrm{mm} \cdot \mathrm{h}^{-1}\right)$ \\
\hline \multirow{5}{*}{0.99} & Fv-C & $1.87 \mathrm{cC}$ & $0.59 \mathrm{aA}$ \\
\hline & Ba-W & $4.39 \mathrm{a}$ & $0.40 \mathrm{c}$ \\
\hline & Ba-PA & $3.06 \mathrm{~b}$ & $0.50 \mathrm{~b}$ \\
\hline & Mo-W & $2.59 \mathrm{~B}$ & $0.56 \mathrm{~B}$ \\
\hline & Mo-PA & $2.90 \mathrm{~A}$ & $0.53 \mathrm{C}$ \\
\hline \multirow{5}{*}{0.98} & $\mathrm{Fv}-\mathrm{C}$ & $3.03 \mathrm{cC}$ & $0.54 \mathrm{aA}$ \\
\hline & Ba-W & $4.24 \mathrm{a}$ & $0.53 \mathrm{a}$ \\
\hline & Ba-PA & $4.11 \mathrm{~b}$ & $0.30 \mathrm{~b}$ \\
\hline & Mo-W & $4.11 \mathrm{~B}$ & $0.37 \mathrm{~B}$ \\
\hline & Mo-PA & $7.42 \mathrm{~A}$ & $0.27 \mathrm{C}$ \\
\hline \multirow{5}{*}{0.97} & $\mathrm{Fv}-\mathrm{C}$ & $3.94 \mathrm{cB}$ & $0.55 \mathrm{aA}$ \\
\hline & Ba-W & $4.09 \mathrm{~b}$ & $0.19 \mathrm{c}$ \\
\hline & Ba-PA & $7.26 \mathrm{a}$ & $0.45 \mathrm{~b}$ \\
\hline & Mo-W & $4.30 \mathrm{~A}$ & $0.49 \mathrm{~B}$ \\
\hline & Mo-PA & $3.84 \mathrm{C}$ & $0.44 \mathrm{C}$ \\
\hline \multirow{5}{*}{0.96} & $\mathrm{Fv}-\mathrm{C}$ & $4.75 \mathrm{bB}$ & $0.38 \mathrm{aA}$ \\
\hline & Ba-W & $5.20 \mathrm{~b}$ & $0.25 \mathrm{~b}$ \\
\hline & $\mathrm{Ba}-\mathrm{PA}$ & $8.56 \mathrm{a}$ & $0.16 \mathrm{c}$ \\
\hline & Mo-W & $4.64 \mathrm{C}$ & $0.39 \mathrm{~A}$ \\
\hline & Mo-PA & $8.47 \mathrm{~A}$ & $0.17 \mathrm{~B}$ \\
\hline
\end{tabular}

Fv-C: F. verticillioides control, growth without antagonistics agents at different water activities; Ba-W: B. amyloliquefaciens without physiological adaptation; Ba-PA: B. amyloliquefaciens physiologically adapted; Mo-W: M. oleovorans without physiological adaptation; Mo-PA: M. oleovorans physiologically adapted. Data with the same letter (small) for different treatment with B. amyloliquefaciens are not significantly different, and data with the same letter (capital) for different treatment with M. oleovorans are not significantly different according to Duncan's multiple range test $(\mathrm{P}<0.05)$.

quality and improve survival during storage biofungicide trade and greater efficiency in the rhizosphere ecosystem, we proceeded to the physiological improvements of $B$. amyloliquefaciens and M. oleovorans [18].

This study have demonstrated the ability to synthesize betaine and ectoine under high-osmolality conditions of B. amyloliquefaciens and M. oleovorans cells, both accumulated large amounts of ectoine, maybe like ectoine synthesis in Bacillus pasteurii is a true osmotic effect rather than a salt-specific response, since both ionic and non-ionic osmolytes trigger the production of ectoine $[21,35]$. Compatible solutes are operationally defined as osmolytes that can be amassed by the cell in exceedingly high concentrations (up to several moles per liter) without disturbing vital cellular functions and the correct folding of proteins [36], the level of compatible solute accumulation is set by the environmental osmolarity [37]. Upon a hypo-osmotic shock, cells can restore the osmotic balance by releasing osmolytes via specific efflux systems, which are mechanosensitive channels different from the uptake systems [38]. Therefore, this strategy enables organisms for rapid adaptation to an osmotically fluctuating environment by simply adjusting the internal solute pool to counteract the osmolarity of the surrounding environment, these solutes serve as stabilisers of proteins and cell components against the denaturing effects of high ionic strength [39]. Compatibles solutes can be accumulated by bacteria by novo synthesis or by transport from the culture medium [20], and is possible to significantly improve environmental stress tolerance of bacterial biocontrol agents by physiologically growing them under conditions which facilitate synthesis of useful compatible solutes such as glycine-betaine and ectoine. This can give cross-protection during formulation against heat stress as well [15]. Studies by Louis et al. [40] showed that ectoine and hydroxyectoine stabilized air-dried and freeze-dried E. coli cells during drying process. Teixidó et al. [15] showed the improvement in 
osmotic and thermal tolerance of cells of the biocontrol agent Pantoea agglomerans CPA-2. The authors showed that compatible solutes glycine-betaine and ectoine play a critical rol in environmental stress tolerance improvement. Our results showed that $M$. oleovorans accumulated the highest content of ectoine when the water activity was reduced to $0.96 \mathrm{a}_{\mathrm{w}}$. The accumulation of betaine and ectoine in cells of B. amyloliquefaciens and M. oleovorans can improve the tolerance of both bacteria to water potential modifications and desiccation in the process of freeze drying and production of formulated.

Etcheverry et al. [41] demonstrated the potential biocontrol agents $M$. oleovorans and B. amyloliquefaciens influenced the growth rate and increased the lag phase of F. verticillioides strains assayed in vitro at different water activities. In this study we obtained a similar result, consequently we can infer that the physiological adaptation leaving a clear unaffected biocontrol potential, by contrary the reduction effect on the growth rate of $F$. verticillioides was higher with cells previously adapted to low water activities.

\section{ACKNOWLEDGEMENTS}

This work was carried out through grants from the Agencia Nacional de Promoción Científica y Tecnológica (ANPCYT) FONCYT-PICT START-UP 1521/06. SECYT-UNRC 2009-2010. Res. 807/09.

\section{REFERENCES}

[1] Bacon, C., Hinton, D. and Richardson, M. (1994) A corn seedling test for resistance to Fusarium moniliforme. Plant Disease, 78, 302-305. doi:10.1094/PD-78-0302

[2] Munkvold, G. and Desjardins, A. (1997) Fumonisins in maize - Can we reduce their occurrence? Plant Disease, 81, 556-565. doi:10.1094/PDIS.1997.81.6.556

[3] Munkvold, G. (2003) Cultural and genetic approaches to managing mycotoxins in maize. Annual Review of Phytopathology, 41, 99-116. doi:10.1146/annurev.phyto.41.052002.095510

[4] Pitt, J. and Hocking, A. (1997) Fungi and food spoilage. 2nd Edition, Blackie Academic and Professional, London. doi:10.1007/978-1-4615-6391-4

[5] CAST (Council for Agricultural Science Technology) (2003) Mycotoxins: Risks in plant, animal, human systems. Task Force Report, Ames, Iowa, No. 139, 1-199.

[6] Thield, P., Sydenham, E., Shepard, G. and Gelderblom, W. (1992) The implication of naturally occuring levels of fumonisin in maize for human and animal health. Mycopathologia, 117, 3-9. doi:10.1007/BF00497272

[7] Chu, F. and Li, G. (1994) Simultaneous occurrence of fumonisin $\mathrm{B}_{1}$ and other mycotoxins in moldy maize collected from people's. Republic of China in regions with high incidences of esophageal cancer. Applied and Environmental Microbiology, 60, 847-852.

[8] IARC (2002) IARC Monographs on the Evaluation of
Carcinogenic Risks to Humans, 82, Traditional Herbal Medicines, Some Mycotoxins, Naphthalene and Styrene. International Agency for Research on Cancer, Lyon, France.

[9] FDA (US Food and Drug Administration) (2001) Guidance for industry: Fumonisin levels in human foods and animal feeds; final guidance.

http://www.fda.gov/Food/GuidanceComplianceRegulator yInformation/GuidanceDocuments/ChemicalContaminantsandPesticides/ucm 109231.htm

[10] European Commission (2007) Commission regulation $1126 / 2007$ setting maximum levels for certain contaminants in foodstuffs as regards Fusarium toxins in maize and maize products. Official Journal European Union, 255, 14-17.

[11] Pereira, P., Nesci, A. and Etcheverry, M. (2007) Effects of biocontrol agents on Fusarium verticillioides count and fumonisin content in the maize agroecosystem: Impact on rhizospheric bacterial and fungal groups. Biological Control, 42, 281-287. doi:10.1016/j.biocontrol.2007.05.015

[12] Pereira, P., Nesci, A. and Etcheverry, M. (2009) Efficacy of bacterial seed treatments for the control of Fusarium verticillioides in maize. BioControl, 54, 103-111. doi:10.1007/s10526-007-9148-3

[13] Pereira, P., Nesci, A. Castillo, C. and Etcheverry, M. (2010) Impact of bacterial biological control agents on fumonisin $\mathrm{B}_{1}$ content and Fusarium verticillioides infection of field-grown maize. Biological Control, 53, 258266. doi:10.1016/j.biocontrol.2010.02.001

[14] Harris, R. (1981) Effect of water potential on microbial growth and activity. In: Parr, J.F., et al., Eds., Water Potential Relations in Soil Microbiology. SSSA Spec. Madison W.I., 9, 23-96.

[15] Teixidó, N., Cañamás, T., Abadías, M, Usall, J., Torres, R., Magan, N. and Viñas, I. (2005) Accumulation of compatible solutes, glycine-betaine and ectoine, in osmotic stress adaptation and heat shock cross-protetion in the biocontrol agent Pantoea agglomerans CPA-2. Letters Applied of Microbiology, 41, 248-252. doi:10.1111/j.1472-765X.2005.01757.x

[16] Teixidó, N., Viñas, I., Usall, J. and Magan, N. (1998) Improving ecological fitness and environmental stress tolerance of the biocontrol yeast Candida sake by manipulation of intracellular sugar alcohol and sugar contet. Mycological Research, 102, 1409-1417. doi:10.1017/S0953756298006716

[17] Mokiou, S. and Magan, N. (2002) Ecophysiological manipulation of the fermentation process improves viability of the biocontrol yeast Pichia anomala. Biocontrol Fungal and Bacterial Plant Pathogens. IOBC/WPRS Bulletin, 25, 395-398.

[18] Sartori, M., Nesci, A. and Etcheverry, M. (2010) Impact of osmotic/matric stress and heat-shock on environmental tolerance induction of bacterial biocontrol agents against Fusarium verticillioides. Research in Microbiology, 161, 681-686. doi:10.1016/j.resmic.2010.06.008

[19] Sartori, M., Nesci, A. and Etcheverry, M. (2011) Production of Fusarium verticillioides biocontrol agents, Bacillus amyloliquefaciens and Microbacterium oleovorans, 
using different growth media: Evaluation of biomass and viability after freeze-drying. Food Additives and Contaminants, Part A. doi:10.1080/19440049.2011.563369

[20] Csonka, L. (1989) Physiological and genetic responses of bacteria to osmotic stress. Microbiological Reviews, 53, 121-147.

[21] Kuhlmann, A. and Bremer, E. (2002) Osmotically regulated synthesis of the compatible solute ectoine in Bacillus pasteurii and related Bacillus spp. Journal of Bacteriology, 68, 772-783.

[22] Record, M., Courtenay, E., Cayley, D. and Guttman, H. (1998) Responses of E. Coli to osmitic stress: Large changes in amounts of cytoplasmic solutes and water. Trends in Biochemical Sciences, 23, 143-148. doi:10.1016/S0968-0004(98)01196-7

[23] Da Costa, M., Santos, H. and Galinski, E. (1998) An overview of the role and diversity of compatible solutes in bacteria and archae. In: Scheper, T., Ed., Advances in Biochemical Engineering/Biotechnology, Springer-Verlag, Berlin, 61, 117-153.

[24] Lentzen, G. and Schwarz, T. (2006) Extremolytes: Natural compounds from extremophiles for versatile applications. Applied Microbiology and Biotechnology, 72, 623-634. doi:10.1007/s00253-006-0553-9

[25] Holt, J. (1993) Bergey's manual of systematic bacteriology. Williams \& Wilkins Co. Baltimore, Maryland.

[26] Dallyn, H. and Fox, A. (1980) Spoilage of material of reduced water activity by xerophilic fungi. In: Gould, G. and Corry, E., Eds., Society of Applied Bacteriology Technical Series, Academic Press, London, 129-139.

[27] Kunte, H., Galinski, E. and Trüper, H. (1993) A modified FMOC-method for the detection of amino acid-type osmolytes and tetrhydropyrimidines (ectoines). Journal of Microbiological Methods, 17, 129-136. doi:10.1016/0167-7012(93)90006-4

[28] Capellini, R. and Peterson, J. (1965) Macroconidium formation in submerged cultures by sporulating strain of Giberella zeae. Mycologia, 57, 962-966. doi: $10.2307 / 3756895$

[29] Cavaglieri, L., Passone, A. and Etcheverry, M. (2004) Screening procedures to select rhizobacteria with biocontrol activity on Fusarium verticillioides growth and fumonisin $\mathrm{B}_{1}$ production. Research in Microbiology, 155, 747-754. doi:10.1016/j.resmic.2004.06.001

[30] Cavaglieri, L., Passone, A. and Etcheverry, M. (2004) Correlation between screening procedures to select root endophytes for biological control of Fusarium verticallioides in Zea mays L. Biological Control, 31, 259-267. doi:10.1016/j.biocontrol.2004.07.006

[31] Cavaglieri, L., Orlando, J. and Etcheverry, M. (2005) In vitro influence of bacterial mixtures on $F$. verticillioides growth and fumonisin $\mathrm{B}_{1}$ production. Effect of seed treatment on maize root colonization. Letters Applied of Microbiology, 41, 390-396. doi:10.1111/j.1472-765X.2005.01785.x

[32] Cavaglieri, L., Andrés, L., Ibañez, M. and Etcheverry, M. (2005) Rhizobacteria and their potential to control Fusarium verticillioides: Effect of maize bacterisation and inoculum density. Antoine Van Leeuwenhoek, 87, 179-187. doi:10.1007/s10482-004-3193-Z

[33] Pereira, P., Nesci, A., Castillo, C. and Etcheverry, M. (2011) Field Studies on the Relationship between Fusarium verticillioides and Maize (Zea mays L.): Effect of biocontrol agents on fungal infection and toxin content of grains at harvest. International Journal of Agronomy. doi: $10.1155 / 2011 / 486914$

[34] Kohl, J. and Fokkema, N. (1998) Strategies for biological control of necrotrofic fungal foliar pathogens. In: Boland, G. and Kuykendall, L. Eds., Plant-Microbe interactions and Biological Control, Marcel Dekker, Inc., New York, 49-88.

[35] Göller, K., Ofer, A. and Galinski, A. (1998) Construction and characterization of an $\mathrm{NaCl}$-sensitive mutant of $\mathrm{Ha}$ lomonas elongata impaired in ectoine biosynthesis. FEMS Microbiology Letters, 161, 293-300.

[36] Brown, A. (1976) Microbial water stress. Bacteriological Reviews, 40, 803-846.

[37] Poolman, B. and Glaasker, E. (1998) Regulation of compatible solute accumulation in bacteria. Molecular Microbiology, 29, 397-307. doi:10.1046/j.1365-2958.1998.00875.x

[38] Morbach, S. and Krämer, R. (2002) Body shaping under water stress: osmosensing and osmoregulation of solute transport in bacteria. Chembiochem, 3, 384-397. doi:10.1002/1439-7633(20020503)3:5<384::AID-CBIC3 84>3.0.CO;2-H

[39] Kempf, B. and Bremer, E. (1998) Uptake and synthesis of compatible solutes as microbial stress responses to highosmolality environments. Archives of Microbiology, 170, 319-330. doi:10.1007/s002030050649

[40] Louis, P., Trüper, H. and Galinski, E. (1994) Survival of Escherichia coli during drying and storage in the presence of compatible solutes. Applied Microbiology and Biotechnology, 41, 684-688. doi:10.1007/BF00167285

[41] Etcheverry, M., Scandolara, A., Nesci, A., Vilas Boas Ribeiro, M., Pereira, P. and Battilani, P. (2009) Biological interactions to select biological agents against toxigenic strains of Aspergillus flavus and Fusarium verticillioides from maize. Mycopathologia, 167, 287-295. doi:10.1007/s11046-008-9177-1 